\title{
A SWOT ANALYSIS OF NEW INVESTMENTS IN BROWN COAL DEPOSITS IN POLAND
}

\author{
Anna Monika Ziętera*
}

Summary:

The purpose of this article is to present factors determining the effectiveness of new investments in brown coal deposits. It discusses the weak and strong points of brown coal mining in Poland, as well as opportunities and risks in its development. The strong point is that Poland has abundant resources of lignite and the opportunity lies in the rising demand for energy. The weak point is that brown coal emits large amounts of $\mathrm{CO}_{2}$ and risk is perceived in that the EU tightens up its policy on coal-based production of energy. An analysis of all these factors allows reliable assessment of the discount rate on investment projects, which must be known for their profitability to be established.

Key words: effectiveness, investment, brown coal mining.

\section{INTRODUCTION}

The national power industry is based on its own reserves of mineral fuels, which mostly consist of hard coal and partly of lignite. The two minerals account for more than $80 \%$ of primary energy generated in Poland, whereby Poland is one the lowest indicators of dependence on primary energy imports ${ }^{1}$. However, because of limited investment activity hard coal output is declining. Concerning brown coal, a similar trend is expected to appear in 2020. Without

*Mgr, absolwent Uniwersytetu Łódzkiego, Wydziału Ekonomiczno-Socjologiczny, kierunku Finanse i Bankowość.

${ }^{1}$ Total production of primary energy... [6 Nov. 2013]; Primary production of coal and lignite... [6 Nov. 2013]; Primary production of crude oil... [6 Nov. 2013]; Primary production of natural gas... [6 Nov. 2013]; Primary production of nuclear energy... [6 Nov. 2013]; Primary production of renewable energy... [6 Nov. 2013]; Energy dependence... [6 Nov.2013]. 
new investments in brown coal deposits its production may definitely come to an end around 2048. To maintain domestic energy balance, efforts are necessary to keep coal output at the present level at least; particularly that demand for energy is rising each year rather than falling [Cała et al. 2012: 38].

Poland can respond to the growing demand for energy by mining its huge deposits of brown coal. Because of probable brown coal deposits Poland ranks fourth in the world, behind the USA, Russia and China. This fact is noteworthy because own deposits of natural resources are a guarantee of energy security of the country. This means that investments in the domestic deposits of brown coal have strategic significance for the future of Poland. As the Polish government shares the opinion, new investments in brown coal deposits may be made out macroeconomic and political reasons so a question must be asked whether they will be profitable from a microeconomic perspective, i.e. whether the investing companies will be able to increase their value through them. To answer the question, the economic effectiveness of such projects must be examined, including the determination of the discount rate which shows what cashflows a project may yield in different periods. A reliable estimation of the discount rate requires that all risks related to the mining of new brown coal deposits be considered. The outcome of the investor's decision, i.e. a success or failure of the project, depends on whether the current and future risks are properly accounted for (this particularly applies to long-term projects), because they will influence the future rate of return on the committed capital.

This article seeks to analyse the strengths, weaknesses, opportunities and risks of new investments in brown coal deposits in Poland with a view to creating a full picture of such projects without which their discount rates cannot be established.

\section{THE STRENGTHS OF BROWN COAL MINING}

The strong point of brown coal mining in Poland is that the country's reserves of this coal are one of the largest in the world and the largest in Europe. Figure 1 below presents the distribution of probable brown coal reserves in the world.

Moreover, because of the knowledge and mastery of mining technology, Polish brown coal industry ranks among the world leaders. Polish mining engineering schools, scientific and design institutes, and the producers of mining technologies and machinery have gained worldwide reputation. For instance, Polish technologies and machinery are used in Greece and India [Wołodkiewicz-Donimirski 2010: 215]. Polish mines and lignite-fired power stations are operated by high-class specialists. The Polish school of brown coal mining 
has been created based on long years of experience [Kasztelewicz and Zajączkowski 2010: 235].

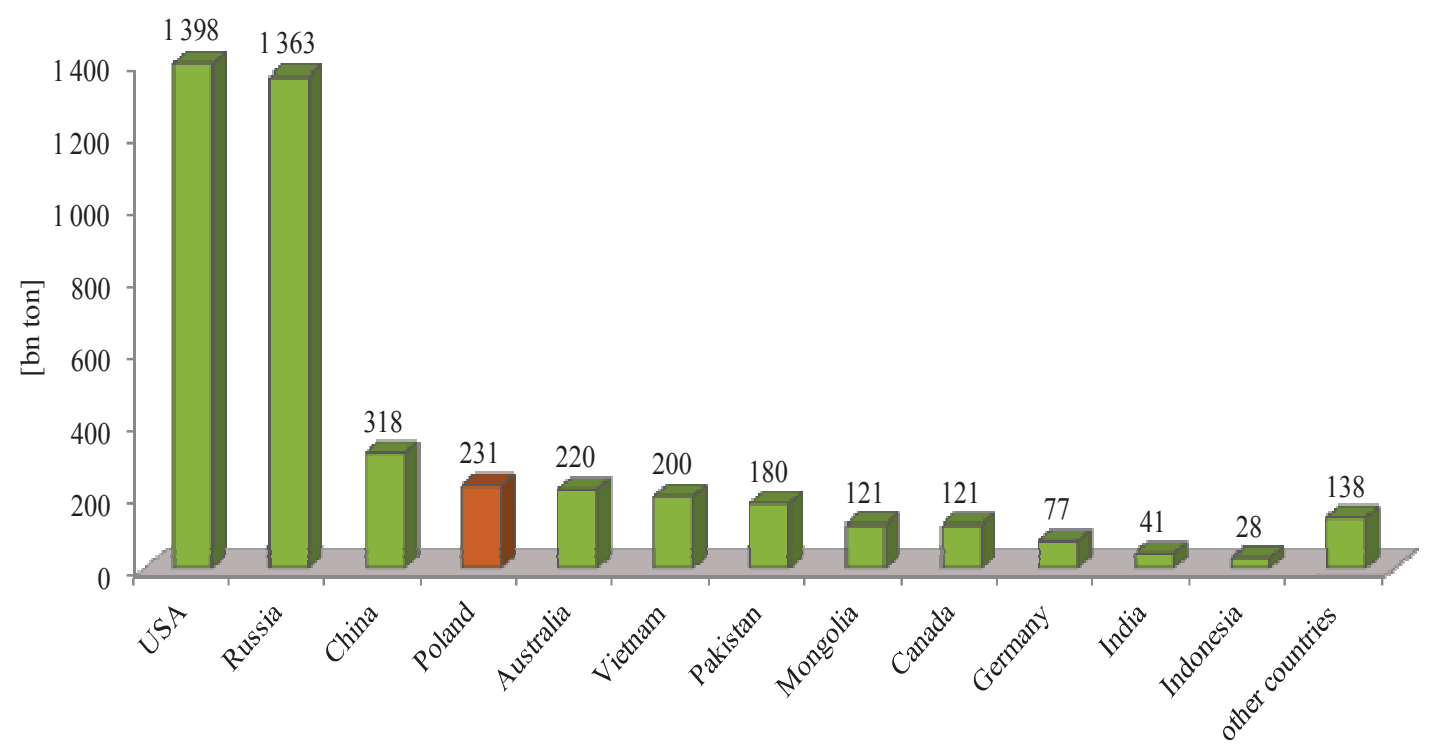

Figure 1. Ranking of probable brown coal reserves in the world

Source: developed by the author based on Energy Study 2012... [20 May 2013].

\section{WEAKNESSES OF BROWN COAL MINING AND RISKS TO ITS EXPANSION}

However, brown coal mining is also vulnerable because burning lignite emits the largest amounts of carbon dioxide among all fossil fuels. A comparison of $\mathrm{CO}_{2}$ emissions by fossil fuel is presented in table 1 .

Table 1. $\mathrm{CO}_{2}$ emissions by fos sil fuels

\begin{tabular}{|c|c|}
\hline Fuel & Unit emission $\left[\mathrm{kg} \mathrm{CO}_{2} / \mathrm{GJ}\right]$ \\
\hline \hline Brown coal & 101.20 \\
\hline Hard coal & 94.60 \\
\hline Crude oil & 74.07 \\
\hline Natural gas & 56.10 \\
\hline
\end{tabular}

Source: developed by the author based on Wołodkiewicz-Donimirski [2010: 208].

This property of brown coal is noteworthy considering the fact that in the last dozen years or so the abatement of $\mathrm{CO}_{2}$ emissions has been a priority for the European Union. One purpose of the climate and energy package it has adopted 
is to cut greenhouse gas emissions (including $\mathrm{CO}_{2}$ ) by at least $20 \%$ against their 1990 level. The vehicle for achieving the purpose is the carbon emissions trading system. It makes power plants buy carbon credits that increase energy production costs and the price of energy as a result. The highest increases concern the brown coal-fired power stations that emit the largest amounts of $\mathrm{CO}_{2}$ and the smallest are observed among the natural gas-fired power stations that emit much less carbon dioxide than the coal-fired power stations. The Ministry of Economy estimates that following the introduction of the carbon credit trading system, after 2020 the nuclear power stations will have the costs of energy production lower by $20 \%$ and $50 \%$ compared, respectively, with the coalfired power stations and the natural gas-fired power stations [takoma, 30.09.2013]. This implies that the expansion of nuclear power generation after 2020 will substantially constrain the development of coal-based power generation (including brown coal mining). This forecast contrasts with W. Mielczarski's predictions, who argues that notwithstanding the introduction of the carbon credit trading system, after 2020 power stations running on brown coal will remain the least expensive source of electrical energy ${ }^{2}$. The predicted costs are the following [Cała et al. 2012: 58]:

- nuclear power stations - over $500 \mathrm{PLN} / \mathrm{MWh}$,

- renewable power stations - over $400 \mathrm{PLN} / \mathrm{MWh}$,

- hard coal-fired power stations - 375 PLN/MWh,

- natural gas-fired power stations - 370 PLN /MWh,

- brown coal-fired power stations - 365 PLN /MWh.

According to the data, the status of the coal-based power industry will not be seriously affected by nuclear or wind power industry. However, the calculations through which they were obtained assumed that the charge on $\mathrm{CO}_{2}$ emission would be 30 euros per ton. W. Mielczarski is of the opinion that it will not exceed 40 euros per ton of carbon dioxide [Mielczarski 2009: 21]. It is, therefore, relevant to ask how the status of the industry will change if the charge is 60 euros per ton of carbon dioxide, as proposed in the „Energy Policy of Poland Until 2030" [Uchwała nr 202/2009 Rady Ministrów z dnia 10 listopada 2009 r...].

In 2011, the European Commission published „A Roadmap for Moving to a Competitive Low Carbon Economy in 2050", which sets three targets for cutting greenhouse gas emissions in the EU: by $40 \%$ to the year 2030 , by $60 \%$ before 2040 , and by as much as $80-95 \%$ by 2050 . The document is only a basis

${ }^{2}$ For many years the lignite-fired power stations have been in Poland the source of the cheapest electrical energy. According to Agencja Rynku Energii SA (the Energy Market Agency), in 2008 the power generation costs in the lignite-fired commercial power stations was 131.44 $\mathrm{PLN} / \mathrm{MWh}$, in hard coal-fired commercial power stations $166.48 \mathrm{PLN} / \mathrm{MWh}$, in gas-fired commercial power stations 251.18 PLN/MWh, and in large wind power stations (with output $<10 \mathrm{MW}$ ) 216.50 PLN/MWh [Wołodkiewicz-Donimirski 2010: 204]. 
for future directives so it is not formally binding [Szyjko 2013: 45]. Even so, it is a major threat to the expansion of brown-coal mining in Poland; the EnergSys reports make it clear that if EU adopts this energy policy coal will be eliminated as a fuel from the production of electrical energy and will be replaced by sources of nuclear and renewable energy ${ }^{3}$.

Another disadvantage of brown coal mining is that not only does it need vast areas of land to produce coal, but it also has a detrimental effect on the natural environment. The massive scale of coal production involving the removal and mixing of huge amounts of overburden dramatically change the landscape: the spoil heap is mounting higher and higher as the pit is being excavated into the ground. A major change in microclimate follows. Farming land and woodlands are excluded from use either temporarily or permanently. Moreover, the necessary deep and surface drainage of the rock mass disturbs groundwater and surface water relations [Kasztelewicz and Zajączkowski 2010: 228].

However, the production process must end at some point in time. The mine has a legal obligation to reclaim the mining site once the deposit has been exhausted ${ }^{4}$. The law makes it also obligatory for mines to accumulate resources necessary to remove the installations over the extraction period. Accordingly, brown coal mines in Poland consistently reclaim and rehabilitate land as mining fronts move forward. The long-standing experience of the Polish mining industry has allowed it to develop and implement effective technologies for restoring original values to the natural environment. Even though the disturbed ground will not look quite the same as it did before mining started, a welldesigned and timely reclamation process may partly make up for this defect, but in the first place it can ensure that once mining is over the site will be fully usable as agricultural land, woodland or a reservoir for tourists. In many cases, a multifaceted reclamation of the site may give it new natural, tourist and recreational values [Badera 2010: 116]. Credit must also be given to mining companies for taking efforts to mitigate other impacts of their activity, such as hydrological changes, etc., by providing local communities with water supply systems and by implementing other corrective measures. Sometime after mining is over water relations recover to almost the original state. To mitigate or eliminate other mining-related problems that may be onerous for the local environment, appropriate technical solutions such as sprinkling or acoustic baffles are implemented [Dubiński and Tajduś 2009: 103, 105].

\footnotetext{
${ }^{3}$ The document was vetoed by the Polish Minister of Environment. Poland has not agreed so far to resume discussions on the document [Niedziółka 2012: 37; Kasztelewicz 2011: 160].

${ }^{4}$ Art. 20 ust. 1 i ust. 4 Ustawy z dnia 3 lutego 1995 r. o ochronie gruntów rolnych i lesinych...
} 
Although mining industries in Poland and Europe can be proud of many land reclamation and rehabilitation projects, in public opinion opencast mining amounts to polluted soil, ruined landscape, and contaminated waters. It is so, because domestic media still present mine sites as „devastated areas devoid of hope for development" [Kasztelewicz and Zajączkowski 2010: 241]. The opponents of the extraction industry frequently claim that once the deposit is exhausted local communities are left ,with big holes in the ground” [Naworyta 2009: 427]. It is true that because brown coal mines need vast open pits they are considered to be particularly damaging to the environment. Their tainted image among the public is a major risk to their expansion, because protesting communities supported by ecological organisations can very effectively thwart their plans for the extraction of new deposits ${ }^{5}$. The expansion of the existing brown coal mines (e.g. the KWB Turów's plans to take over part of OpolnoZdrój), or the establishment of new mining sites in the vicinity of the operating ones (e.g. by KWB Bełchatów in Szczerców) has not sparked major protests, because local communities already knew about the real environmental impacts of mining activity (an exception to this pattern is the widely publicized conflict around the exploitation of the Tomisławice site by KWB Konin). Where the industry is new and local communities have limited knowledge about opencast mining conflicts appear, such as protests around the attempted exploitation of the Legnica, Rogoźno, and Gubin deposits [Baca and Kałucki 2011; Kałucki and Baca 2009; Badera 2010: 110].

The conclusion arising from the above is that mining industry should take more efforts to improve its public image. A good solution would be a well-targeted and coordinated information and education policy explaining the real impacts of mining on the environment, the nature of the possible preventive measures, and the ways of offsetting the impacts developed by the industry. For mining companies, appropriate information policy should be part of public relations and a basis for negotiations with local opponents if need be. It also seems important that local communities and local governments be familiarised with the environmental aspects of lignite mining as well as with the benefits that investment projects may bring to them. That brown coal mines significantly improve the local labour market, increase municipalities' incomes, and stimulate business in the local area may not be known to an average citizen [Badera 2010: 121]. Communities living around mining sites benefit financially from high rates of property tax and royalties. The funds can be allocated to projects that frequently address local environmental needs, such as treatment plants, sewage systems, water supply systems, and dumping sites [Naworyta 2009: 427]. In all

\footnotetext{
${ }^{5}$ A mining company intending to extract a brown coal deposit must receive permission from the local authorities, from the local community living close to the site, and from environmental organisations.
} 
these communities current income per capita is much above the national average for Poland, while the rate of unemployment is below the national average. With the current per capita income of 35,247 PLN (in 2010) the municipality of Kleszczów is the wealthiest community in Poland (the 2010 national average was 1,208 PLN). Its incomes are so high because of Elektrownia Bełchatów (a power plant) and KWB Bełchatów (a brown coal mine) operating in its area [Kasztelewicz and Zajączkowski 2010: 239-240].

Communities try to prevent brown coal mines from entering into their areas not only to save the natural environment from devastation, but also because local residents do not feel like selling their houses to mines and moving outside the mining sites. Many sites above the proven reserves of coal have been urbanized for the lack of laws effectively protecting them from above-ground development and infrastructure [Cała et al. 2012: 103]. This situation increases the investment costs of new open pits or even prevents their construction for fear of likely clashes with local communities [Kasztelewicz and Ptak 2009: 271]. It must be noted, however, that the transfers of land for lignite mining purposes have not created any conflicts as yet, because the land excluded from public use was mainly agricultural and developed with rural dwellings (and not urbanized) [Badera 2010: 110]. Even so, because development processes take up greater and greater areas above coal deposits, it is necessary to enact laws specifying how the deposits, which are part of the natural environment and a resource of raw materials for future generations, should be protected. Mineral resources ought to enjoy the same degree of protection as other components of the natural environment [Naworyta 2009: 432].

\section{OPPORTUNITIES FOR THE DEVELOPMENT OF BROWN COAL MINING}

One the opportunities that the lignite mining industry can use to develop is the support from the Polish government that understands that substantial domestic reserves of hard and brown coal determine the energy security of the country. The support has materialised in the document „Poland's Energy Policy Until 2030", which indicates that coal will remain the primary fuel for the power industry because it can provide the country with an appropriate level of energy self-sufficiency. Because the domestic demand for energy is rising, a reduction in the production capacity of the hard and brown coal mining industry would entail larger imports of natural gas, crude oil, hard coal, or uranium to fill the gap. Even if the output of the renewable energy sector were bigger than it is today, the energy self-sufficiency of Poland would be seriously hurt [Cała et al. 2012: 106]. This, and the fact that the currently extracted deposits of coal are running low made the authors of the government document stress the need to 
prepare and start the extraction of new deposits. Further, because investments are key stimulants of economic growth, it becomes necessary to create more favourable investment conditions for companies that account for a large proportion of investments in the economy [Stawska 2014: 161]. The document enumerates the following forms of government support for coal mining industry: backing for research and development work on clean coal technologies, ensuring that natural resources are protected in zoning plans, and granting the status of public-purpose ventures of above-local importance to investment projects in the mining industry [Uchwała nr 202/2009 Rady Ministrów z dnia 10 listopada 2009 r...].

The developing research on clean coal technologies (CCTs) is another expansion opportunity for brown coal mining. The purpose of the technologies is to improve the efficiency of coal extraction, processing, conversion and use, and to make the processes more acceptable, as they are perceived as detrimental to the natural environment [Cała et al. 2012: 61]. The R\&D centres in Poland and in the world have for many years been working on implementing various CCTs. The global leaders are mining industry research centres in the USA, Germany, China and Australia. The Polish research institutions working in this field are the AGH University of Science and Technology in Krakow, the Silesian University of Technology, the Central Mining Institute, and Institute for Chemical Processing of Coal [Kasztelewicz 2011: 160].

CCTs can be basically divided into three categories: technologies increasing the efficiency of brown coal conversion into electrical energy, $\mathrm{CO}_{2}$ capture and storage technologies, and technologies for converting brown coal into fluid and gas fuels. The more detailed descriptions of the technologies are presented in table 2 .

The development and large-scale implementation of CCTs can make brown coal much more efficient as an electricity-generating fuel, as well as enabling its use in the production of various chemical compounds, including fluid and gas fuels. The implementation of CCT technologies would largely advance the modernisation of coal-based power generation and would allow it to leave behind its image of an ,obsolete" industry. The importance of developing technologies for cutting $\mathrm{CO}_{2}$ emissions arises from the fact that they can allow the power industry to effectively confront the challenges of EU's environmental policy. With carbon capture and storage technologies and with technologies increasing power units' efficiency the coal-fired power stations could reduce their $\mathrm{CO}_{2}$ emissions as expected.

The strengths, weaknesses, opportunities and threats to the development of brown coal mining are concisely presented in table 3 . 
Table 2. An outline of CCTs

\begin{tabular}{|c|c|}
\hline \multicolumn{2}{|c|}{ Technologies improving the efficiency of converting brown coal into electricity } \\
\hline $\begin{array}{l}\text { The drying of } \\
\text { brown coal }\end{array}$ & $\begin{array}{l}\text { Crushed coal is fed into a drying chamber where water is vaporised and } \\
\text { removed at a temperature of } 110^{\circ} \mathrm{C} \text {. This technology can improve power } \\
\text { stations' efficiency of electricity production by } 4-6 \% \text {. Pilot installations that } \\
\text { utilise it are being tested in two power stations in Germany. }\end{array}$ \\
\hline $\begin{array}{l}\text { Power units } \\
\text { working at } \\
\text { supercrtitical steam } \\
\text { parameters }\end{array}$ & $\begin{array}{l}\text { Power units working at supercritical parameters allow higher average } \\
\text { efficiency of electricity and heat production, within the range of } 44-46 \% \text {. In } \\
\text { Poland, the technology has been implemented in new power units in Pątnów } \\
\text { II and Bełchatów. Research work has reached the stage of demonstration } \\
\text { projects with units working at supercritical steam parameters that can } \\
\text { generate electricity with efficiency of 55\%. }\end{array}$ \\
\hline $\begin{array}{l}\text { Oxygen-enriched } \\
\text { combustion of coal }\end{array}$ & $\begin{array}{l}\text { Coal combustion emissions contain around } 80 \% \text { of nitrogen, whereas an } \\
\text { oxygen-enriched combustion process emits almost exclusively carbon } \\
\text { dioxide and steam. The process significantly facilitates } \mathrm{CO}_{2} \text { storage, as well } \\
\text { as making it unnecessary to extract } \mathrm{CO}_{2} \text { from the emissions. The first pilot } \\
\text { installation generating electricity from brown coal burned in oxygen- } \\
\text {-enriched environment and extracting } \mathrm{CO}_{2} \text { was set up in Germany in } 2008 \text {. }\end{array}$ \\
\hline IGCC & $\begin{array}{l}\text { The IGCC technology is used to gasify coal to generate combustible gas } \\
\text { which is then burned in a combined cycle configuration. Its advantages are } \\
\text { potentially high efficiency of electricity production (even up to } 60 \% \text { ) and the } \\
\text { possibility of generating hydrogen. Based on the knowledge gained during } \\
\text { tests with an experimental installation, a brown coal-fired IGCC power } \\
\text { station is being designed now. }\end{array}$ \\
\hline \multicolumn{2}{|r|}{$\mathrm{CO} 2$ capture and storage technology } \\
\hline \multicolumn{2}{|c|}{$\begin{array}{l}\text { The technology allows capturing } \mathrm{CO}_{2} \text { generated during coal combustion and transporting it to } \\
\text { appropriate geological formations where it is pumped underground to prevent its contact with } \\
\text { atmosphere. Although single components of the CCS technology - the capture, transportation and } \\
\text { storage of } \mathrm{CO}_{2}-\text { are already well known and used, the challenge lies in integrating them into } \\
\text { a generally available technology. At present, the CCS technology is being developed to make it } \\
\text { useful for the power industry. The lignite-fired power station Bełchatow in Poland has been } \\
\text { indicated by the EU as the site of one of } 12 \mathrm{CCS} \text { pilot installations. Pilot projects using this } \\
\text { technology are already operational in the EU, China and Norway. }\end{array}$} \\
\hline \multicolumn{2}{|c|}{ Technologies for converting brown coal into liquid and fluid fuels } \\
\hline $\begin{array}{l}\text { Above-ground coal } \\
\text { gasification }\end{array}$ & $\begin{array}{l}\text { The technology is used to gasify coal in above-ground installations. Around } \\
125 \text { coal gasification facilities have been constructed, of which } 5 \text { use brown } \\
\text { coal. }\end{array}$ \\
\hline $\begin{array}{l}\text { Underground coal } \\
\text { gasification }\end{array}$ & $\begin{array}{l}\text { Air, oxygen or steam is pumped underground to gasify coal, i.e. to convert it } \\
\text { from a solid state into gas. The technology can be used to extract coal that } \\
\text { cannot be reached using traditional mining methods. The present stage of the } \\
\text { technology development in Poland aims to set up pilot tests and to construct } \\
\text { the demonstration installations. }\end{array}$ \\
\hline $\begin{array}{l}\text { Biogasification of } \\
\text { brown coal }\end{array}$ & $\begin{array}{l}\text { This technology consists in the anaerobic digestion of brown coal by special } \\
\text { strains of bacteria that convert organic matter into gas. Numerous laboratory } \\
\text { tests with this technology are being carried out at present. }\end{array}$ \\
\hline
\end{tabular}

Source: developed based on Cała et al. [2012: 61-66]; Wołodkiewicz-Donimirski [2010: 209-210]. 
Table 3. SWOT analysis of the development of brown coal mining in Poland

\begin{tabular}{|l|l|}
\hline \hline \multicolumn{1}{|c|}{ Strengths } & \multicolumn{1}{c|}{ Weaknesses } \\
\hline $\begin{array}{l}\text { substantial reserves of coal, } \\
\text { intellectual potential, world-class scientific } \\
\text { and technical resources, } \\
\text { experienced workforce, }\end{array}$ & $\begin{array}{l}\text { lignite-fired power stations generate large amounts } \\
\text { of } \mathrm{CO} 2, \\
\text { mines need large expanses of land to produce coal, } \\
\text { negative impact of mining on the natural } \\
\text { environment, }\end{array}$ \\
\hline \hline \multicolumn{1}{|c|}{ Opportunities } & \multicolumn{1}{c|}{ Threats } \\
\hline $\begin{array}{l}\text { Polish government understands the } \\
\text { importance of domestic coal reserves, } \\
\text { steadily rising demand for electrical energy, }\end{array}$ & $\begin{array}{l}\text { high costs of carbon credits, } \\
\mathrm{CO}_{2} \text { emissions policy being gradually tightened up, } \\
\text { lack of laws effectively protecting the proven } \\
\text { reserves against above-ground development and } \\
\text { infrastructure, } \\
\text { negative perception of brown coal mining among } \\
\text { the public. }\end{array}$ \\
\hline
\end{tabular}

Source: developed by the author.

\section{CONCLUSIONS}

To correctly determine how effective new investments in brown coal deposits can be all the above strengths, weaknesses, opportunities and threats in the development of this industry must be carefully quantified and analysed. A risk premium proportional to the amount of risk added to the discount rate increases the requirements an investment should meet and therefore offers some margin of safety. Then, even if the investment performs worse than expected, there is still a chance that it will not turn out unprofitable. A project without this margin should not be given the green light [Sierpińska and Jachna 2007: 513].

New investments in brown coal deposits are liable to many factors that may affect their economic effectiveness. Financial analysts who assess this effectiveness must, for instance, take account of political considerations, the attitudes of local residents, or technologies that may become available in the future. It is therefore difficult to establish what discount rate an investment project will have, particularly that the future costs of $\mathrm{CO}_{2}$ emissions are uncertain. An analyst who is overly optimistic about project performance may lead into bankruptcy not only the investing mine and the nearby power station, but also many companies that work for them.

Investments in new brown coal deposits in Poland, one of the largest in the world, are of strategic importance for the country's future. The main reasons for making them will be macroeconomic and political. From the microeconomic perspective, it seems rational for investing companies to seek ways to improve the effectiveness of their projects (by addressing factors presented in the article) and thereby to increase their value. 


\section{REFERENCES}

Baca K., Kałucki J., 2011, Antywęglowa koalicja spod Legnicy rośnie w siłe, „Rzeczpospolita”, no. 131.

Badera J., 2010, Konflikty społeczne na tle środowiskowym zwiazane z udostępnianiem złóż kopalin w Polsce, „Gospodarka Surowcami Mineralnymi”, vol. 26, fascicle 1.

Cała M., Kasztelewicz Z., Tajduś A., 2012, Węgiel kamienny i węgiel brunatny, [in:] K. Jeleń, M. Cała (eds.), Zarys stanu i perspektywy energetyki Polskiej, Wydawnictwo AGH, Kraków.

Dubiński J., Tajduś A., 2009, Szanse i zagrożenia polskiego górnictwa węgla brunatnego w świetle uwarunkowań światowych i europejskich, „Górnictwo i Geoinżynieria”, fascicle 2.

Energy dependence, Eurostat, epp.eurostat.ec.europa.eu/tgm/table.do?tab=table\&init=1\&plugin $=1 \&$ language $=$ en\&pcode $=$ tsdcc310.

Energy Study 2012. Reserves, Resources and Availability of Energy Resources, German Mineral Resources Agency, Federal Institute for Geosciences and Natural Resources (Hannover), www.bgr.bund.de/DE/Gemeinsames/Produkte/Downloads/DERA_Rohstoffinformationen/ro hstoffinformationen-15e.pdf?_blob=publicationFile \&v $=3$.

Łakoma A., Pieniądze sa największą bariera, www.ekonomia.rp.pl/artykul/329872.html.

Kałucki J., Baca K., 2009, Gminy zamrożone na lata, „Rzeczpospolita”, no. 280.

Kasztelewicz Z., Ptak M., 2009, Wybrane problemy zabezpieczania złóż węgla brunatnego w Polsce dla odkrywkowej działalności górniczej, „Polityka energetyczna”, vol. 12, fascicle 2/2.

Kasztelewicz Z., 2011, Wplyw polityki klimatycznej UE na górnictwo i energetykę Polski, „Zeszyty Naukowe Instytutu Gospodarki Surowcami Mineralnymi i Energią Polskiej Akademii Nauk", no. 81.

Kasztelewicz Z., Zajączkowski M., 2010, Wpływ działalności górnictwa węgla brunatnego na otoczenie, „Polityka energetyczna”, vol. 13, fascicle 2.

Mielczarski W., 2009, Elektrownie atomowe. Obliczenia kosztów, „Energetyka Cieplna i Zawodowa", no. 10.

Naworyta W., 2009, Wpływ uwarunkowań środowiskowych na możliwość racjonalnej gospodarki zasobami złóż węgla brunatnego w Polsce, „Polityka energetyczna”, vol. 12, fascicle 2/2.

Niedziółka T., 2012, Energetyczna Mapa Drogowa 2050. UE nie może się „wyrywać”, „Energia Gigawat", no. 7-8.

Primary production of coal and lignite, Eurostat, epp.eurostat.ec.europa.eu/tgm/table.do?tab= table\&init $=1 \&$ plugin $=1 \&$ language $=$ en \&pcode $=$ ten 00077 .

Primary production of crude oil, Eurostat, epp.eurostat.ec.europa.eu/tgm/table.do?tab=table\& init $=1$ \&plugin $=1$ \&language $=$ en\&pcode $=$ ten 00078 .

Primary production of natural gas, Eurostat, epp.eurostat.ec.europa.eu/tgm/table.do?tab=table\& init $=1$ \&plugin $=1$ \&language $=$ en\&pcode $=$ ten 00079 .

Primary production of nuclear energy, Eurostat, epp.eurostat.ec.europa.eu/tgm/table.do?tab= table \&init $=1 \&$ plugin $=1 \&$ language $=$ en \&pcode $=$ ten 00080 .

Primary production of renewable energy, Eurostat, epp.eurostat.ec.europa.eu/tgm/table.do?tab= table\&init $=1 \&$ plugin $=1 \&$ language $=$ en $\&$ pcode $=\operatorname{ten} 00081$.

Sierpińska M., Jachna T., 2007, Metody podejmowania decyzji finansowych. Analiza przykładów i przypadków, Wydawnictwo Naukowe PWN, Warszawa.

Stawska J., 2014, Stopy procentowe a inwestycje w Polsce i strefie euro, Wydawnictwo Uniwersytetu Łódzkiego, Łódź.

Szyjko C. T., 2013, Energetyka - czas trudnych wyborów, „Fakty - magazyn gospodarczy”, no. 3.

Total production of primary energy, Eurostat, epp.eurostat.ec.europa.eu/tgm/table.do?tab=table\& init $=1$ \&plugin $=1$ \&language $=$ en\&pcode $=$ ten 00076

Uchwała nr 202/2009 Rady Ministrów z dnia 10 listopada 2009 r. „Polityka energetyczna Polski do 2030 roku". 
Finanse i Prawo Finansowe • Journal of Finance and Financial Law • 2014, vol. 3, s. 93-104 Anna Monika Ziętera, A SWOT Analysis of New Investment...

Ustawa z dnia 3 lutego 1995 r. o ochronie gruntów rolnych i leśnych, DzU 1995, no. 16, item 78, as amended.

Wołodkiewicz-Donimirski Z., 2010, Uwarunkowania rozwoju górnictwa węgla brunatnego w Polsce, ,Studia BAS”, no. 1. 